San Jose State University

From the SelectedWorks of Karthika Sasikumar

June 21, 2017

\title{
After nuclear midnight: The impact of a nuclear war on India and Pakistan
}

Karthika Sasikumar, San Jose State University 
Contact: karthika.sasikumar@sjsu.edu

\title{
After nuclear midnight: The impacts of a nuclear war in India and Pakistan
}

\author{
Karthika Sasikumar
}

\begin{abstract}
During the past decade, computer models have predicted that the physical impacts of a nuclear exchange between India and Pakistan, or even a single strike on a large city, would be devastating. The social, economic, and political impacts-although less well known-would also be crippling, and would reverberate throughout the world. Efforts to use "Armageddon estimates" to scare the people of India and Pakistan have thus far not significantly reduced the risk of nuclear weapons use in this turbulent region. However, the increasing penetration of television and social media may give members of the public a better grasp of the scale of potential devastation. Combined with educational efforts targeted at media elites, increased public awareness of the consequences of a nuclear attack may help to reduce the pressure on political leaders to exercise the nuclear option.
\end{abstract}

\section{KEYWORDS}

Armageddon, demonstration effect, fragility, India, nuclear security, NUKEMAP, Pakistan, political effects

Sometimes it is important to think about the unthinkable. Although South Asia has been called "the most dangerous place in the world" by former US President Bill Clinton and others (Marcus 2000), the discourse in those countries, and elsewhere, about the potential aftermath of a nuclear exchange between India and Pakistan has been remarkably muted. What would these two enduring rivals, home to more than a sixth of the world's population, look like after a nuclear exchange?

Experts can estimate, albeit in general and speculative terms, the consequences of nuclear use in India and Pakistan. Computer models and simulations show that the physical consequences of even a "small" nuclear war between the two countries would be catastrophic in terms of lost lives, radiation releases, and climate repercussions. Less well known, though, are the social and geopolitical impacts of such an exchange, which would also be devastating-and would create ripple effects in other countries.

Researchers and peace activists have tried to raise public awareness of "Armageddon estimates," but their efforts have thus far had limited effectiveness. A better public understanding of the full range of aftermath impacts would help leaders to pursue policies that stabilize this region.

\section{How far to nuclear midnight?}


Given the current force structure and doctrine in these two countries, what is the probability and magnitude of a potential use of nuclear weapons? Pakistan is estimated to have a stockpile of 130 to 140 warheads (Kristensen and Norris 2016). India has produced an estimated 110 to 120 nuclear warheads (Kristensen and Norris 2015). India has developed a ballistic missile submarine, the Arihant, capable of firing nuclear warheads, while Pakistan is in the process of developing its own sea-based deterrent (Davenport 2017). India has a whole arsenal of nuclear-capable missiles-with ranges from 250 kilometers to 5,000 kilometers (Kristensen and Norris 2015). However, India's warheads would most likely be delivered by one of its bomber aircraft. Pakistan would need to use missiles as the delivery system, because India is a much larger target.

A study of Indian and Pakistani doctrines makes it clear that nuclear use is being considered seriously. India has adopted a No First Use policy, and its official doctrine is based on massive retaliation (Prime Minister's Office 2003). However, New Delhi has signaled that it retains the option of nuclear use at lower levels of the escalation ladder-that is, that it might carry out a nuclear attack in response to a threat that falls below the threshold of an attack on its very existence (Faisal et al. 2017). There are two reasons behind this. Attacks on Indian civilian centers and military bases, by militants who are allegedly backed by Pakistan, anger the public and put pressure on New Delhi to act. Moreover, some Indian leaders believe that intervention by major powers - the United States in particular-is likely to "freeze" an India-Pakistan confrontation at an early stage, thus giving the advantage to Pakistan if it makes the first move. There are some indications that India is considering counterforce strikes against Pakistani nuclear assets in the early stages of a military confrontation (Faisal et al. 2017). Also, India's No First Use policy has been eroded by verbiage threatening nuclear use in retaliation for biological or chemical attacks on Indian forces (Sagan 2009).

Given its inferiority in conventional warfare and its smaller size, Pakistan chose not to adopt a No First Use policy. Its leaders have indicated that their threshold for nuclear use, in the face of an Indian attack, is on the lower side (Carnegie Endowment for International Peace 2015: 9). Accordingly, although it has operational medium-range ballistic missiles-including some that can reach the Indian mainland-in recent years, Pakistan has focused on developing short-range, nuclear-capable missiles. Of these, the Nasr, which has a 60-kilometer range, is clearly intended for battlefield use (and worryingly, more vulnerable to theft or unauthorized use because it would most likely be deployed during active combat, when commanders would be given pre-delegated authority to launch in the field).

The risk of an unauthorized nuclear detonation, whether by accident or by subversion, must also be considered. In the atmosphere of mutual distrust that characterizes India-Pakistan relations, an unauthorized or accidental detonation might well trigger retaliatory attacks. There is no guarantee that a limited nuclear exchange would not escalate.

The behavior of the leaders of India and Pakistan during crises is not reassuring either; both sides have made explicit nuclear threats. Remarkably, while the international community was extremely alarmed by the potential for nuclear weapons use, the people of both countries were more sanguine. They appeared to have more faith in the strength of mutual deterrence than the world's experts. In the most recent crisis, in October 2016, the Indian government conducted "surgical strikes" across the Line of Control (the military line between Indian and Pakistani controlled areas in the disputed Kashmir region) on terrorist camps that were allegedly launching attacks on India. A poll of potential voters in a regional election days later, showed that 91 percent of respondents supported the strikes (Singh 2016).

\section{Modeling the physical consequences of nuclear war}


It seems likely that those supporting nuclear use lack an understanding of its aftermath. On the one hand, it is possible that they see a nuclear weapon as just another, perhaps larger, bomb. On the other hand, if the public believes that the use of one nuclear bomb would cause catastrophic destruction over an enormous area, they might be willing to support nuclear threats in the belief that nobody would actually use such a bomb. Ideally, the public should have a realistic picture of the effects of nuclear weapons.

NUKEMAP, a free online program developed by Alex Wellerstein, a historian of nuclear weapons at the Stevens Institute of Technology, offers a Google Maps "mashup" for modeling the impact of nuclear detonations. Hyderabad, in South Central India, is the fifth-largest metro area in the country. It is a possible site for a first strike by Pakistan. Hyderabad is a big enough target to send a strong signal to the adversary, but it is on a lower rung of the escalation ladder than India's largest cities. It also happens to be home to India's Nuclear Fuel Complex-which might be manufacturing nuclear weapon cores. It is possibly a manufacturing and storage site for India's short-range Prithvi missiles.

Exploding a 20-kiloton bomb (the equivalent of the "Fat Man" bomb dropped on Nagasaki, Japan) over Hyderabad, India, produces around 436,000 immediate fatalities. The fatality estimates depend on, among other things, the time of day that the detonation takes place. If the explosion was to be near the surface rather than in the air, the casualties would be halved, but the bomb would produce devastating radiation over 13 square kilometers.

NUKEMAP also has the option to show the destruction of vital infrastructure, such as hospitals and fire stations. With an airburst detonation, which would maximize damage to buildings, Hyderabad would lose nearly 150 medical facilities (based on Google Maps designations, which might not be completely accurate).

If the site of the initial detonation is India's capital New Delhi, which would be a top countervalue target, NUKEMAP predicts that a 20-kiloton explosion above the administrative center of the city (Parliament House, the presidential residence, and North and South Block-home to the major ministries) produces 260,000 immediate fatalities and close to 100,000 injuries. Detonating the same warhead over a different part of Delhi, with fewer administrative installations but a higher population density, would increase the casualties. A surface burst would cause radiation of 100 rads per hour (enough to cause acute radiation syndrome) over 182 square kilometers-some of the most densely populated areas of the world. If New Delhi were to be targeted with a 100-kiloton surface burst, even if only half of the material undergoes fission, the radiation at 100 rads per hour could spread all the way to the border with Pakistan, if the winds are blowing in that direction.

If India were to attack Pakistan with a 20-kiloton bomb, detonated in the air, one possible target would be Islamabad, the capital city. Since it is newer and less densely-populated, Islamabad would fare better than New Delhi, experiencing approximately 100,000 casualties.

NUKEMAP uses publicly available information, and provides an interface that allows users to set different parameters for detonations on any sites of their choosing. It draws on Google Maps, as well as databases of the average population in specific areas, and uses standard calculations of physical effects. The estimates mentioned here should be taken with caution, since they are based on imperfect knowledge of local conditions. Casualty estimates will vary depending on the time of day, the exact location of Ground Zero, temperature, air pressure, direction of the wind, the sturdiness of new 
construction, whether the population had advance warning, and so on. Wellerstein's model is explicit about its assumptions, and the limitations thereof.

Experts have also created more scientific models of specific scenarios. In the last decade, when it seemed that the risk of a nuclear exchange between the United States and Russia had dwindled, scientists turned their attention to modeling the effects of nuclear use in South Asia. Their models assume lower yields for individual warheads, as well as a smaller number of detonations, than Cold War models.

Even with these downsized assumptions, environmental scientist Alan Robock and atmospheric scientist Owen Brian Toon found that tens of millions of people could die if India and Pakistan used most of their arsenals in a nuclear exchange (Robock and Toon 2012). Earlier simulations by Robock, Toon, and several other colleagues predicted that 100 Hiroshima-size (15-kiloton) warheads detonated in airburst mode above South Asian cities would inject so much soot into the atmosphere that global average precipitation would drop by nearly $10 \%$ for a few years afterward-and even after a decade, global average surface air temperatures would remain 0.5 degrees Celsius ( 0.9 degrees Fahrenheit) below normal (Robock et al. 2007).

The famine that would result could affect more than a billion people, according to a 2012 briefing paper by physician Ira Helfand. Using a model of the global economy, the paper found that a regional nuclear war between India and Pakistan would cause malnutrition among 215 million people across the world over a decade, and would also put at risk the 925 million people who are already chronically malnourished (Helfand 2012). Helfand's estimate for the number of people who would be added to the rolls of the malnourished is on the lower side, since it assumes that markets continue to operate normally.

As modeling techniques improve, assumptions specific to South Asia can be incorporated. For instance, Stanford University climate change researcher Stephen $\mathrm{H}$. Schneider posited that in the event of a nuclear explosion, because the sun is stronger in the sub-tropical latitudes, heated plumes of smoke would loft higher into the stratosphere than in the northern latitudes (Lee 2007). The resulting "nuclear winter" would therefore be more severe. It is also vital to consider the effects of a South Asian nuclear war on the Himalayan watershed, the primary source of water and sustenance for a third of the world's population. Nepali journalist and ecologist Kunda Dixit has predicted that fallout would diffuse eastward to the Tibetan plateau, injecting radioactivity into this fragile ecosystem (Ghosh 2008: 91). In more complex analyses, the particularities of fuel use (such as the ubiquitous liquified petroleum gas cylinders that are found in most urban homes and restaurants in South Asia), and the specific percentages of combustible material in various South Asian cities, would be taken into account.

\section{The social and political impacts of a regional war}

Effects on the physical environment are only one part of what we need to know about the aftermath of a nuclear attack. Urban planners, sociologists, and ecologists need to estimate the effects on social infrastructure. The novelist Amitav Ghosh predicts in Countdown, a journalistic account of a hypothetical 15-kiloton nuclear attack on New Delhi: "Millions and millions of people will begin to walk. Many will be nursing burn wounds and other severe injuries. There will be no food, no clean water, and no prospect of medical care. Epidemics will break out" (Ghosh 2008: 80-81). 
There is less than one hospital bed per 1,000 residents in India and Pakistan (The World Bank, undated). Even in India's capital, only 1.4 beds are available per thousand residents (The Times of India 2011). Interestingly, the major hospitals in New Delhi are located very near the administrative center of the city, a potential Ground Zero discussed above. Experts believe that civil defense will be extremely difficult to implement in India and Pakistan (Rajaraman, Mian, and Nayyar 2004). Deficits in space and financial resources hinder both governments and private individuals from stockpiling vital items.

The political effects on India and Pakistan are even harder to predict. The word resilience is often used to describe India's stable multi-party democracy, which thrives amid poverty and strident identity conflicts. On international indices such as the Fragile States Index, India continues to post relatively heartening scores (The Fund for Peace 2016). Yet its economic and social infrastructure is often unable to cope with the strains of a rapidly growing population and economy. It is likely to buckle in the face of the massive disruption that a nuclear attack would cause. The 2008 attack on the commercial capital, Mumbai, by a small band of militants originating in Pakistan, exposed many gaping holes in the national emergency response system (Rabasa et al. 2009). Even heavier-than-normal rainfall has paralyzed Mumbai for days.

In the event of an attack by Pakistan, India's sizable Muslim minority (approximately 170 million) could face retaliation from the Hindu majority, triggering communal riots (Pakistan has a very small Hindu minority). Some experts have argued that more religiously-minded governments in Pakistan would hesitate to order a nuclear strike, knowing that both the detonation and the post-attack retaliation would menace Muslims in India (Naim 1998). However, there have been terrorist attacks on locations where Muslims were killed, therefore this cannot be relied on as a deterrent.

Pakistan's polity is undoubtedly more fragile. On the most recent Fragile States Index, Pakistan ranks 14th, while India occupies the 70th place (The Fund for Peace 2016). More worryingly, Pakistan has been trending downward in the last five years on most indicators of fragility. Political instability has been a permanent feature of the Pakistani state. However, in the last three decades, the country has been riven by a deeper debate about its very identity. In 2002, under severe international pressure to resolve a border standoff with India, Pakistan's Prime Minister had to remind his people in a major speech: "Pakistan is our identity, our motherland" (New York Times 2002). Although he affirmed that "The verdict of the masses is in favour of a progressive Islamic state," the religious extremists that he was inveighing against continue to push for a hardline theocracy. In the last decade, heavily armed militant groups have attacked major sites like the Red Mosque in the capital, Pakistan Navy Headquarters, and a military-run school in Peshawar.

When it comes to safeguarding their nuclear assets, both India and Pakistan fare badly. In the most recent ranking by the Nuclear Threat Initiative, they rank fourth and third from the bottom, respectively, for preventing the theft of nuclear materials (NTI 2016: 20). An investigative report by the Center for Public Integrity found major problems with theft, personnel reliability, and safety procedures in India Levy and Smith 2014). Across the border in Pakistan, the biggest worries are about a takeover of the government, either by a faction of the military or an Islamic militant group-or a combination of these two. The possibility of the diversion of weapons-usable material to militants also remains high.

In the event of a nuclear attack, the leaders of both countries would likely face intense, sustained pressure to respond both to the casualties and the provocation. In a 2012 survey, nearly $60 \%$ of Indians and Pakistanis saw each other as "very serious threats" (Pew Research Center 2012). In September 2016, after an attack on an Indian Army base, social media users demanded, in astonishingly high 
numbers (Saxena 2016), that India use the nuclear option against Pakistan (which is suspected to have aided the attackers). Pakistani leaders have also accused India of fomenting domestic unrest in the volatile border regions of Pakistan, and have reiterated their intent to retaliate (Geo News 2016).

\section{Geopolitical fallout}

How would the world react to Armageddon in India and Pakistan? Their immediate neighbors, already poor and unstable, would be badly affected by the economic and ecological disaster of nuclear use. Bangladesh and Nepal would brace themselves for an exodus of refugees from India. The consequences for China would be mostly ecological, although Beijing would worry about the lessons that its weaker, unstable ally North Korea would draw. In fact, this "demonstration effect" would be the starkest concern for leaders in the rest of the world, once they had begun to cope with the disruption of communication, trade routes, information technology infrastructure, and climatic conditions.

The last use of nuclear weapons was 72 years ago. Since then, the use of nuclear weapons has become unthinkable, almost a taboo. But the taboo is not automatic or permanent; it is maintained through the efforts of military strategists, experts, and politicians to delegitimize the idea that nuclear weapons are just another instrument of war. If deterrence fails in South Asia, leaders of some countries will face increased pressure to acquire nuclear weapons. This may be true of US allies in Asia (Japan, South Korea, and Taiwan), as well as middle-power countries elsewhere that had turned their backs on the nuclear weapons option in the past (Australia, Egypt, and South Africa). In the volatile Middle East, Iran, Israel, and Saudi Arabia would probably be most affected by this pressure. The United States would have to mitigate this pressure by offering stronger security guarantees.

It is possible that witnessing a nuclear catastrophe would impel citizens and political leaders to launch a new campaign for nuclear elimination. However, this seems unlikely for two reasons. First, in the shortand medium-term, leaders would be distracted by the task of managing the consequences of the nuclear exchange (for instance, finding new suppliers for essential imports). Second, the main obstacles to disarmament that exist today (reliance on deterrence among the major powers, a lack of trust in international verification mechanisms, and the entrenched power of the military-industrial-scientific complex) will persist.

Russia and the United States would have to grapple with the consequences of nuclear use in South Asia. While their economies would undoubtedly be affected, the superpowers would be able to recover. Imports from India were only $2.1 \%$ of total US imports in 2015, and India was the United States' 18 th largest goods export market in 2016 (Office of the United States Trade Representative, undated). However, both the United States and Russia would face the reality that their maneuverings had failed to prevent catastrophe in South Asia. Their standing in the international community would be damaged. They would be called upon to assist in the rebuilding of both societies, at great economic cost. This would especially be true for the United States, which has designated Pakistan as a major non-NATO ally, and is simultaneously seeking to strengthen relations with India.

\section{Public awareness and pressure}

In recent years, part of the nuclear disarmament movement has been focusing on the potential humanitarian impacts of atomic weapons (Ossoff 2016). The political use of what might be called "Armageddon estimates" is an interesting aspect of nuclear diplomacy in South Asia. Whether they will 
affect policy choices in the region hinges on an important question: Do most Indians and Pakistanis understand what the effects of a nuclear exchange would be? Anti-nuclear-weapons activists have attempted to spread awareness of these effects, but are stymied by low literacy, low media penetration, and lack of interest in the issue among politicians. A better grasp of the scale of the devastation may give members of the public pause before they demand that their leaders exercise the nuclear option (although images of nuclear devastation may also increase the public's attachment to existing arsenals for protection). Interestingly, Alex Wellerstein (personal communication) found that Indians and Pakistanis represent only approximately $15 \%$ of the total number of NUKEMAP users setting off detonations on "enemy" countries. This is probably an artifact of the relatively low number of Internet users in India and Pakistan.

Let us also consider that India and Pakistan are among the world's most turbulent places. They are among the countries most targeted by terrorists: Pakistan is fourth and India is sixth on a major global terrorism index (Institute for Economics \& Peace 2015). Pakistan has been ranked among the 10 countries with the highest number of deaths due to terrorism for a decade now. Living with constant chaos, fear, and poverty has made many Indians and Pakistanis demand that their governments conduct a massive nuclear strike on the enemy "to end the terror once and for all." This sense of hopelessness, mixed with the psychic numbness that nuclear weapons seem to promote, mitigates the horror of a nuclear Armageddon.

Consequently, efforts from outside the region to "scare them straight" by providing estimates of the consequences of a nuclear attack may be less than successful. In 2002, during a tense border standoff between India and Pakistan that included nuclear threats, a "leaked" report from the US Defense Department estimated that up to 12 million people would die instantly in the event of a full-scale nuclear exchange, and another 7 million would be gravely injured (Shanker 2002). Only disclosures by those in power at the time will reveal whether these estimates had an effect.

Is it possible to spread awareness of the aftermath of a nuclear explosion among the publics in India and Pakistan? Low literacy is not necessarily a barrier to such efforts if the right medium is chosen. Although traditional print media reach only a quarter of the population in India, television consumption is increasing-estimates are that 475 million people (more than a third of the population) watch television every day (Dasgupta 2016). India also has about 375 million Internet subscribers, with the majority of them accessing the Internet on their mobile phones. In the last few years, there has been an explosion of social media in both India and Pakistan. This new media sector exercises a huge influence over political behavior-as evidenced by the three-year ban on YouTube in Pakistan because of fears that it was used to stoke violent protests (Wilkes 2016).

Can increased public awareness be translated into political action? This is the more difficult step in the process. While both countries are democracies (Pakistani democracy is newer, but has been thriving for a decade now), elections center on bread-and-butter issues. It is difficult to imagine a mainstream political party discussing nuclear policy during a campaign. Efforts to spread awareness would be better targeted at "influencing the influencers." The objective should be to encourage India's new media elites-journalists for online publications, bloggers, talk show hosts, and so on-to become aware of the costs and challenges of a nuclear attack. As part of this process, presentation of the results of scientific simulations in simple terms, and providing access to simulators like NUKEMAP, would be a good start.

\section{Disclosure statement}


No potential conflict of interest was reported by the author.

\section{Notes on contributor}

Karthika Sasikumar is an associate professor of political science at San Jose State University, and an affiliate of the Center for International Security and Cooperation at Stanford University. Previously, she was a program associate at the American Academy of Arts and Sciences and an associate in the International Security Program at Harvard University's Kennedy School of Government. She began her education in India, where she earned master's and M.Phil. degrees from the School of International Studies in New Delhi. She received her Ph.D. from the Department of Government at Cornell University.

\section{References}

Carnegie Endowment for International Peace. 2015. "A Conversation with Gen. Khalid Kidwai." Carnegie International Nuclear Policy Conference 2015, March 23. http://carnegieendowment.org/files/03-230315carnegieKIDWAI.pdf

Dasgupta, P. 2016. “Media Penetration: A Sneak into Households." The Economic Times, July 14. http://blogs.economictimes.indiatimes.com/et-commentary/media-penetration-a-sneak-intohouseholds/

Davenport, K. 2017. "India, Pakistan Escalate Military Rivalry." Arms Control Today, March. https://www.armscontrol.org/act/2017-03/news/india-pakistan-escalate-missile-rivalry

Faisal, M., T. Kulkarni, R. Neog, S. A. Sial, and SAV Editorial Staff. 2017. “\#NukeFest2017 Hot Takes: Potential Indian Nuclear First Use?" South Asian Voices, March 20. https://southasianvoices.org/sav-dc-nukefest2017-potential-indian-nuclear-first-use/

Geo News. 2016. "Pakistan Ready to Respond if Provoked, Maleeha Warns India." Geo Television Network, September 30. https://www.geo.tv/latest/116339-Limits-to-Pakistans-restraint-ifIndia-continues-provocation-warns-Maleeha

Ghosh, A. 2008. Countdown. New York: Penguin.

Helfand, I. 2012. "Nuclear Famine: A Billion People at Risk." International Physicians for the Prevention of War and Physicians for Social Responsibility. http://www.psr.org/nuclear-weapons/nuclearfamine-report.pdf

Institute for Economics \& Peace. 2015. Global Terrorism Index 2015. http://economicsandpeace.org/wpcontent/uploads/2015/11/Global-Terrorism-Index-2015.pdf

Kristensen H.M. and S. Norris. 2015. "Indian Nuclear Forces, 2015." Bulletin of the Atomic Scientists 71(5): 77-83. http://www.tandfonline.com/doi/full/10.1177/0096340215599788\#abstract 
Kristensen H.M. and S. Norris. 2016. "Pakistani Nuclear Forces, 2016." Bulletin of the Atomic Scientists 72(6): 368-376. http://www.tandfonline.com/doi/full/10.1080/00963402.2016.1241520

Lee, B. D. 2007. "Climate Scientists Describe Chilling Consequences of a Nuclear War." Stanford News Service, January 8. http://news.stanford.edu/news/2007/january10/schneidersr-011007.html

Levy, A. and R. J. Smith. 2014. "India's Nuclear Explosive Materials are Vulnerable to Theft, U.S. Officials and Experts Say." The Center for Public Integrity, October 8. https://www.publicintegrity.org/2015/12/17/18922/india-s-nuclear-explosive-materials-arevulnerable-theft-us-officials-and-experts

Marcus, J. 2000. “Analysis: The World's Most Dangerous Place?” BBC News, March 23. http://news.bbc.co.uk/2/hi/south asia/687021.stm

Naim, S. R. 1998. "Aadhi Raat Ke Baad (After Midnight)." Program in Arms Control \& Domestic and International Security, University of Illinois at Urbana-Champaign. http://hdl.handle.net/2142/44

New York Times. 2002. “In Musharraf's Words: 'A Day of Reckoning.' “ January 12. http://www.nytimes.com/2002/01/12/international/in-musharrafs-words-a-day-ofreckoning.html

Nuclear Threat Initiative (NTI). 2016. The 2016 NTI Nuclear Security Index: Theft and Sabotage. Washington, DC: Nuclear Threat Initiative. January. http://ntiindex.org/wpcontent/uploads/2016/03/NTI 2016-Index-Report MAR-25-2.pdf

Office of the United States Trade Representative. Undated. "India: U.S.-India Bilateral Trade and Investment." https://ustr.gov/countries-regions/south-central-asia/india

Ossoff, W. 2016. "Climate Science, Nuclear Strategy, and the Humanitarian Impacts Initiative." Bulletin of the Atomic Scientists, August 10. http://thebulletin.org/climate-science-nuclear-strategy-andhumanitarian-impacts-debate9770

Pew Research Center. 2012. "India and Pakistan." Chapter 2 in Deepening Economic Doubts in India: Strong Support for Improving Relations with Pakistan. September 10. http://www.pewglobal.org/2012/09/10/chapter-2-india-and-pakistan/

Prime Minister's Office. 2003. "Cabinet Committee on Security Reviews Progress in Operationalizing India's Nuclear Doctrine." Press release, January 4. http://pib.nic.in/archieve/Ireleng/lyr2003/rjan2003/04012003/r040120033.html

Rajaraman, R., Z. Mian, and A. H. Nayyar. 2004. "Nuclear Civil Defence in South Asia: Is It Feasible?" Economic and Political Weekly: 5017-5026. November 20. https://www.princeton.edu/sgs/faculty-staff/zia-mian/Nuclear-Civil-Defense-in-So-Asia.pdf

Rabasa, A., R. D. Blackwill, P. Chalk, K. Cragin, C. C. Fair, B. A. Jackson, B. M. Jenkins, S. G. Jones, N. Shestak, and A. J. Tellis. 2009. "The Lessons of Mumbai." https://www.rand.org/content/dam/rand/pubs/occasional papers/2009/RAND OP249.pdf 
Robock, A. and O. B. Toon. 2012. "Self-Assured Destruction: The Climate Impacts of Nuclear War." Bulletin of the Atomic Scientists 68(5): 66-74. http://www.tandfonline.com/doi/full/10.1177/0096340212459127

Robock, A., L. Oman, G. L. Stenchikov, O. B. Toon, C. Bardeen, and R. P. Turco. 2007. "Climatic Consequences of Regional Nuclear Conflicts." Atmospheric Chemistry and Physics 7: 2003-2012. http://www.atmos-chem-phys.net/7/2003/2007/acp-7-2003-2007.pdf

Sagan, S. D. 2009. "The Evolution of Pakistani and Indian Nuclear Doctrine." In Inside Nuclear South Asia, edited by S. D. Sagan, 219-263. Stanford, CA: Stanford University Press.

Saxena, V. (ed.). 2016. “Twitter Goes 'Nuclear' in Its Anger Over Uri Terror Attack." India Today, September 19. http://indiatoday.intoday.in/story/twitter-nuclear-war/1/768114.html

Shanker, T. 2002. "12 Million Could Die at Once in an India-Pakistan Nuclear War." New York Times, May 27. http://www.nytimes.com/2002/05/27/world/12-million-could-die-at-once-in-an-indiapakistan-nuclear-war.html

Singh, A. K. 2016. "If Opinion Poll is Right, Modi Doesn't Need Development Promise to Win UP." DailyO, October 14. http://www.dailyo.in/politics/india-today-axis-bip-victory-up-polls-2017-modi-shahsurgical-strikes/story/1/13424.html

The Fund for Peace. 2016. Fragile States Index 2016. (J. J. Messner, ed.). Washington, DC: The Fund for Peace. http://library.fundforpeace.org/library/fragilestatesindex-2016.pdf

The Times of India. 2011. "Country's Med Capital to Get 3,000 More Beds." July 16. http://timesofindia.indiatimes.com/city/chennai/Countrys-med-capital-to-get-3000-morebeds/articleshow/9243427.cms

The World Bank. Undated. "Hospital Beds (Per 1,000 People)." http://data.worldbank.org/indicator/SH.MED.BEDS.ZS

Wellerstein, A. 2012-2017. NUKEMAP. http://nuclearsecrecy.com/nukemap/

Wilkes, T. 2016. "Pakistan Lifts Ban on YouTube after Launch of Local Version." Reuters, January 19. http://www.reuters.com/article/us-pakistan-youtube-idUSKCNOUW1ER 